\title{
INTERPRETING "PLACE OF PUBLIC ACCOMMODATION" UNDER TITLE III OF THE ADA: A TECHNICAL DETERMINATION WITH POTENTIALLY BROAD CIVIL RIGHTS IMPLICATIONS
}

\author{
MATTHEW A. STOWE
}

\section{INTRODUCTION}

In response to its finding that approximately forty-three million Americans have one or more mental or physical disabilities, Congress enacted the Americans with Disabilities Act of 1990 (ADA). ${ }^{1}$ Congress's purposes in enacting the ADA were "to provide a clear and comprehensive national mandate for the elimination of discrimination against individuals with disabilities" and to "bring persons with disabilities into the economic and social mainstream of American life." "3 To those ends, the protections Congress afforded to the disabled under the ADA extend to numerous aspects of public life, including employment, ${ }^{4}$ public services such as transportation, ${ }^{5}$ and public accommodations. ${ }^{6}$

Title III of the ADA, the subchapter addressing public accommodations, sets forth a general prohibition on discrimination: "No individual shall be discriminated against on the basis of disability in the full and equal enjoyment of the goods, services, facilities,

Copyright (C) 2000 by Matthew A. Stowe.

1. See Pub. L. No. 101-336, § 2(a)(1), 104 Stat. 327, 328 (codified at 42 U.S.C. §§ 1210112213 , § 12101(a)(1) (1994)) (finding that currently forty-three million Americans have one or more disabilities and "this number is increasing as the population as a whole is growing older").

2. 42 U.S.C. $§ 12101(b)(1)$ (1994).

3. H.R. REP. NO. 101-485, pt. 2, at 22 (1989), reprinted in 1990 U.S.C.C.A.N. 303, 304. The genesis of this seminal legislation was the recognition that, despite the extraordinary efforts of advocates for the disabled, many disabled Americans lived their lives in intolerable isolation and dependence. See id. at 32, reprinted in 1990 U.S.C.C.A.N 303, 313.

4. $\quad$ See 42 U.S.C. $\$ \S 12111-12117$.

5. See id. $\$ \S 12131-12165$.

6. See id. $\$ \S 12181-12189$. 
privileges, advantages, or accommodations of any place of public accommodation by any person who owns, leases (or leases to), or operates a place of public accommodation." "Although the language of Title III defines place of "public accommodation" and the Department of Justice (DOJ) has supplemented and clarified that definition in applicable regulations, ${ }^{9}$ courts have expressed substantial disagreement about its meaning. ${ }^{10}$ The principal point of contention is whether the term "place of public accommodation" is narrowly limited to physical places or whether it encompasses something more. ${ }^{11}$ Because Title III prohibits discrimination in places of public accommodation, a narrow construction of this term limits the applicability of Title III and raises the question of whether such a narrow construction comports with the express purposes of the ADA. $^{12}$

7. Id. § 12182(a).

8. Id. $\S 12181(7)$.

9. See 28 C.F.R. § 36.104 (1999). The Attorney General has authority to promulgate regulations under the ADA. See 42 U.S.C. § 12186(b).

10. Compare Parker v. Metropolitan Life Ins. Co., 121 F.3d 1006, 1014 (6th Cir. 1997) (holding that "places of public accommodation" are limited to physical places), with Carparts Distribution Ctr. v. Automotive Wholesaler's Ass'n, 37 F.3d 12, 19 (1st Cir. 1994) (holding that "establishments of public accommodation" are not limited to physical structures).

11. See Ford v. Schering-Plough Corp., 145 F.3d 601, 613-14 (3d Cir. 1998) (recognizing a circuit split concerning whether "place of public accommodation" is limited to physical structures).

12. Though the judicial resolution of the meaning of "place of public accommodation" under Title III may appear to be a relatively minor determination, it has decidedly important implications for the disabled community and may even more broadly impact civil rights protections of other minority groups. To illustrate the practicality of this judicial determination, consider the applicability of Title III's nondiscrimination provision to insurance policies. Insurance offices are specifically designated as places of public accommodation in the text of Title III, see 42 U.S.C. $\$ 12181(7)(F)$, and it thus violates Title III to discriminate against a disabled individual "in the full and equal enjoyment of the goods [and] services" of an insurance office. Courts construing "place of public accommodation" narrowly have held that because employer-sponsored insurance policies are acquired at an individual's workplace rather than an insurance office, Title III does not apply to such policies. See Ford, 145 F.3d at 612-13; Parker, 121 F.3d at 1010. Other courts have held that a broader interpretation of "place of public accommodation" is required, noting that it would be "irrational to conclude that persons who enter an [insurance] office to purchase services are protected by the ADA," while those who obtain their policy through an employer, by mail, or by the Internet are not protected. Carparts, 37 F.3d at 19; accord Cloutier v. Prudential Ins. Co. of Am., 964 F. Supp. 299, $301-02$ (N.D. Cal. 1997). In adopting this broader interpretation, courts have signaled that Title III guarantees the disabled more than mere access to physical structures. See, e.g., Kotev v. First Colony Life Ins. Co., 927 F. Supp. 1316, 1321 (C.D. Cal. 1996) (holding that the plain meaning of the statute demonstrates that Title III is not restricted to proscribing only the denial of physical access to disabled persons). 
In Part I, this Note sets forth and briefly discusses the text of Title III, focusing on the statute's definition of "place of public accommodation." Part II extensively examines insurance-related cases interpreting "place of public accommodation" under Title III. Because most litigation regarding the meaning of "place of public accommodation" has arisen in the insurance context, it is unsurprising that most commentators have analyzed the meaning of the term in the context of Title III's applicability to insurance policies. ${ }^{13}$ However, the debate over the meaning of Title III does not stop there, and if, as some suggest, insurance policies require special treatment under Title III, ${ }^{14}$ the interpretation of "place of public accommodation" in other contexts should be further examined. ${ }^{15}$ Indeed, Section II.D demonstrates that, although the insurance cases provide valuable analysis, a normative definition of "place of public accommodation" is better informed by examining cases beyond those involving insurance claims. Accordingly, Part III examines a line of cases determining whether membership organizations are "places of public accommodation" and thus subject to Title III's discrimination prohibition. Part IV uses a hypothetical example to argue that "place of public accommodation" under Title III should be interpreted broadly. It argues not only that "places of public accommodation" are not limited to physical places but also that the term should be interpreted to include membership organizations with no ties to physical facilities. Part $\mathrm{V}$ recognizes that this argument is in tension

13. See, e.g., Jill L. Schultz, Note, The Impact of Title III of the Americans with Disabilities Act on Employer-Provided Insurance Plans: Is the Insurance Company Subject to Liability?, 56 WASH. \& LEE L. REV. 343 passim (1999) (examining whether Title III provides disabled Americans with a cause of action against insurance companies because of discriminatory employer-provided insurance plans); Karen M. Volkman, Comment, The Limits of Coverage: Do Insurance Policies Obtained Through an Employer and Administered by Insurance Companies Fall Within the Scope of Title III of the Americans with Disabilities Act?, 43 ST. LOUIS U. L.J. 249 passim (1999) (suggesting that the policy underlying the ADA calls for a broad interpretation of the statute so as to encompass employer-provided insurance policies).

14. See Schultz, supra note 13, at 380 (arguing that a DOJ publication specifically addressing insurance policies under the ADA should be relied upon in insurance cases rather than the DOJ regulations that ordinarily apply to Title III).

15. Other determinations that have directly turned on whether places of public accommodation are limited to physical structures include, for example, whether a child with attention deficit disorder could be excluded from a youth hockey league, see Elitt v. U.S.A. Hockey, 922 F. Supp. 217, 218 (E.D. Mo. 1996), whether a youth baseball league could disallow a disabled a child with cerebral palsy to "play-down" in a lower age bracket, see Shultz v. Hemet Youth Pony League, Inc., 943 F. Supp. 1222, 1224 (C.D. Cal. 1996), and whether NFL television "blackout" rules impermissibly deny deaf persons access to live broadcasts of football games, see Stoutenborough v. NFL, Inc., 59 F.3d 580, 581-82 (6th Cir. 1995). 
with analogous jurisprudence interpreting "place of public accommodation" under the Civil Rights Act of 1964 (CRA) but proposes means of reconciling this Note's interpretation of "place of public accommodation" under Title III of the ADA with existing analogous CRA case law.

\section{The LAnguage of Title III: TeXtuAl Ambiguity}

Laden with ambiguous new legal terms, ${ }^{16}$ the ADA has become a rich source of litigation in its short history. Rather than elucidating the meaning of Title III of the ADA, court decisions and agency regulations have heaped ambiguity upon ambiguity through inconsistent use of Title III's terms. ${ }^{17}$ Any effort to resolve intelligibly the ambiguity in Title III must begin by analyzing its text. ${ }^{18}$

Section 302(a) of the ADA states that "[n]o individual shall be discriminated against on the basis of disability in the full and equal enjoyment of the goods, services, facilities, privileges, advantages, or accommodations of any place of public accommodation by any person who owns, leases (or leases to), or operates a place of public accommodation." ${ }^{19}$ Although the statute does not technically define "place of public accommodation," it provides a list of private entities that are considered "public accommodations" when their operations affect commerce..$^{20}$ In actuality, however, when the statute defines "public accommodation," it is in fact defining "place of public accommodation"; a "public accommodation" is the entity that operates, owns, or leases the place of public accommodation. ${ }^{21}$ Failure

16. See H.R. REP. No. 101-485, pt. 1, at 59-60 (1989), reprinted in 1990 U.S.C.C.A.N 267, 298 (identifying the House of Representatives' concern that the bill contains vague and confusing new legal terms, causing its interpretation to be conducted mainly by the judiciary rather than Congress).

17. See infra notes 30-114 and accompanying text.

18. See, e.g., Bank of Am. Nat'l Trust \& Sav. Ass'n v. 203 N. LaSalle St. Partnership, 526 U.S. 434, 459 (1999) (Thomas, J., concurring) ("Our precedents make clear that an analysis of any statute ... must not begin with external sources, but with the text itself."); New York State Conference of Blue Cross \& Blue Shield Plans v. Travelers Ins. Co., 514 U.S. 645, 655 (1995) (stating "we begin as we do in any exercise of statutory construction with the text of the provision in question").

19. 42 U.S.C. $\$ 12182(a)$ (1994).

20. See id. §12181(7).

21. See 28 C.F.R. pt. 36, app. B., at 622 (1999). At this point, it is appropriate to clarify the ambiguity in terms in order to establish a vocabulary for discussion. While section 302(a) of the ADA prohibits discrimination against the disabled in places of public accommodation, see 42 U.S.C. § 12182(a), the statute defines only "public accommodation" but not "place of public accommodation." See id. § 12181(7). Substituting the statute's definitional examples of "public 
to differentiate between these two terms has contributed to the confusion in the law's interpretation.

Because the central inquiry of this Note is whether places of public accommodation are limited to actual physical structures, it is important to examine the examples of places of public accommodation provided in the statute. ${ }^{22}$ The examples of places of

accommodations" (e.g., theaters, libraries, places of recreation) into the text of section 302(a) yields nonsensical results. Under such a technical application of the statute's definition of "public accommodation," section 302(a) would prohibit discrimination against the disabled in "any place of a theater" or "any place of a place of recreation." Further obfuscating the meaning of Title III is the fact that courts have used the terms "place of public accommodation" and "public accommodation" interchangeably. See, e.g., Erwin v. Northwestern Mut. Life Ins. Co., 999 F. Supp. 1227, 1232-33 (S.D. Ind. 1998) (stating both that "the clear connotation of the words in $\S 12181(7)$ is that a public accommodation is a physical place" and that "[t]he establishments enumerated in $\S 12181(7)$ clearly show that a 'place of public accommodation' is a physical place") (emphasis added).

Pursuant to its authority under the ADA, the DOJ has promulgated regulations to implement the provisions of Title III. See 42 U.S.C. \$ 12186(b) (1994). In its regulations, the DOJ attempts to resolve the ambiguity deriving from the text of Title III by clearly distinguishing "place of public accommodation" from "public accommodation." See 28 C.F.R. pt. 36, app. B, at 622 (1999) (defining both "place of public accommodation" and "public accommodation"). Indeed, the regulations indicate that when Congress defined "public accommodation" in section 301(7) of the ADA, it was in actuality defining "place of public accommodation." See id. ("The term 'place of public accommodation' is an adaptation of the statutory definition of 'public accommodation' in section 301(7) of the ADA ...."). The term "public accommodation," on the other hand, refers to "the private entity that owns, leases (or leases to), or operates a place of public accommodation." Id. By drawing this distinction, the DOJ is able to conclude that the discrimination prohibition of section 302(a) applies to public accommodations in the context of their ownership, leasing, or operation of places of public accommodation. See id. This resolves the aforementioned textual absurdity associated with a technical reading of Title III; the substitution of the DOJ's language into section 302(a) results in a prohibition of discrimination against the disabled in the "full and equal enjoyment of the goods [and] services ... of any place of public accommodation by a public accommodation." See 42 U.S.C. § 12182(a) (1994). This not only avoids the nonsensical prohibition of discrimination in, for example, "any place of a place of recreation," but it develops an operative vocabulary for a clearer discussion of the scope of Title III.

22. The full definition of "public accommodation" reads:

The following private entities are considered public accommodations for purposes of this subchapter, if the operations of such entities affect commerce-

(A) an inn, hotel, motel, or other place of lodging, except for an establishment located within a building that contains not more than five rooms for rent or hire and that is actually occupied by the proprietor of such establishment as the residence of such proprietor;

(B) a restaurant, bar, or other establishment serving food or drink;

(C) a motion picture house, theater, concert hall, stadium, or other place of exhibition or entertainment;

(D) an auditorium, convention center, lecture hall, or other place of public gathering;

(E) a bakery, grocery store, clothing store, hardware store, shopping center, or other sales or rental establishment; 
public accommodation listed in the statute are divided into twelve groups. ${ }^{23}$ For example, one category of entities that may be places of public accommodation includes "a gymnasium, health spa, bowling alley, golf course, or other place of exercise or recreation." ${ }^{24}$ Those examples are clearly physical places. In fact, most of the examples in the definitional list, and arguably all, are actual physical places. Some examples, however, such as "travel service," are arguably not physical places; such arguments are explored in Part II of this Note.

In addition to the definitional list provided in the text of the statute, applicable DOJ regulations define places of public accommodation as "facilities," 25 which, under a plain and ordinary reading, are physical structures. ${ }^{26}$ Because the DOJ has authority to promulgate regulations to implement the $\mathrm{ADA},{ }^{27}$ and because courts defer to agency regulations that are not arbitrary or contrary to the statute, ${ }^{28}$ the inquiry into whether places of public accommodation are limited to physical structures ought to be relatively brief. However, an abundance of judicial decisions disagreeing about whether places of

(F) a laundromat, dry-cleaner, bank, barber shop, beauty shop, travel service, shoe repair service, funeral parlor, gas station, office of an accountant or lawyer, pharmacy, insurance office, professional office of a health care provider, hospital, or other service establishment;

(G) a terminal, depot, or other station used for specified public transportation;

(H) a museum, library, gallery, or other place of public display or collection;

(I) a park, zoo, amusement park, or other place of recreation;

(J) a nursery, elementary, secondary, undergraduate, or postgraduate private school, or other place of education;

(K) a day care center, senior citizen center, homeless shelter, food bank, adoption agency, or other social service center establishment; and

(L) a gymnasium, health spa, bowling alley, golf course, or other place of exercise or recreation.

42 U.S.C. § 12181(7) (1994).

23. See id.

24. Id. §12181(7)(L).

25. 28 C.F.R. pt. 36, app. B, at 622 .

26. See Brown v. 1995 Tenet ParaAmerica Bicycle Challenge, 959 F. Supp. 496, 498 (N.D. Ill. 1997) (“"F]acility' ... appears clearly to be defined as a physical structure.”) (quotations omitted). Furthermore, the regulations define "facility" as "all or any portion of buildings, structures, sites, complexes, equipment . . .” 28 C.F.R. § 36.104 (1999).

27. See 42 U.S.C. § 12186(b) (1994) (declaring that "the Attorney General shall issue regulations in an accessible format to carry out the provisions of this subchapter not referred to in [section 12186(a)]").

28. See Chevron U.S.A. Inc. v. Natural Resources Defense Council, Inc., 467 U.S. 837, 84344 (1984) (stating that agency interpretations are given controlling weight by courts if they are reasonable and not "arbitrary, capricious, or manifestly contrary to the statute"). 
public accommodation are limited to actual physical structures suggests otherwise. ${ }^{29}$

An analysis of existing case law is warranted to help determine not only whether places of public accommodation under Title III are limited to actual physical places but also to determine whether they should be. Moreover, in light of the DOJ regulations defining "place of public accommodation" as a "facility," cases holding that "places of public accommodation" do not have to be physical places should be examined to determine whether they fail to consider the regulations, consciously disregard the regulations as contrary to the statute, or accept the regulations with alternative reasoning for their holding. Further, a finding that places of public accommodation should not be limited to physical structures invites an analysis of which non-physical entities could constitute places of public accommodation.

\section{INSURANCE CASES: THE EPICENTER OF DEBATE}

Although Title III safeguards the right of disabled citizens to be free from discriminatory treatment in a broad variety of contexts, nowhere have complaints about violations of Title III's discrimination prohibitions arisen more frequently than in the insurance context. Cases addressing the applicability of Title III to insurance policies are numerous, dealing chiefly with a small set of issues: whether policy provisions limiting benefits for AIDS-related illnesses are discriminatory under Title III ${ }^{30}$ whether it violates Title III for a longterm disability insurance policy to provide disparate levels of coverage for mental, as opposed to physical, disabilities absent actuarial support for such a distinction; ${ }^{31}$ whether refusal to insure an

29. See infra notes 30-114 and accompanying text.

30. See Doe v. Mutual of Omaha Ins. Co., 179 F.3d 557, 558 (7th Cir. 1999) (allowing a claim against an insurer that limited benefits for AIDS-related conditions to $\$ 25,000$ or $\$ 100,000$, while benefits for other conditions were limited to $\$ 1$ million); Carparts Distribution Ctr., Inc. v. Automotive Wholesaler's Ass'n, 37 F.3d 12, 14 (1st Cir. 1994) (reversing a dismissal of a claim against an insurer whose plan limited benefits for AIDS-related illnesses to $\$ 25,000$ ); World Ins. Co. v. Branch, 966 F. Supp. 1203, 1203 (N.D. Ga. 1997) (holding that a policy cap limiting lifetime benefits for AIDS treatment to $\$ 5,000$ violated Title III).

31. See Ford v. Schering-Plough Corp., 145 F.3d 601, 603-04 (3d Cir. 1998) (addressing a plan that extended coverage for physical disabilities until age 65, yet extended coverage for mental disabilities for a maximum of two years); Parker v. Metropolitan Life Ins. Co., 121 F.3d 1006, 1008 (6th Cir. 1997) (same); Conners v. Maine Med. Ctr., 42 F. Supp. 2d 34, 37 (D. Me. 1999) (same); Erwin v. Northwestern Mut. Life Ins. Co., 999 F. Supp. 1227, 1228 (S.D. Ind. 1998) (same); Lewis v. Aetna Life Ins. Co., 982 F. Supp. 1158, 1159 (E.D. Va. 1997) (same). 
individual based on disability, often in the absence of sound actuarial data to support such a refusal, violates Title III $;^{32}$ and whether it violates Title III to charge a disabled person a higher rate for life insurance without actuarial data supporting the higher rate. ${ }^{33}$ Although the facts of these inquiries vary, the core question involved in each of them is whether Title III's nondiscrimination provision reaches the content of insurance policies. ${ }^{34}$

In answering this question, courts have first examined the threshold question of whether discrimination in the terms of an insurance policy is included in the penumbra of discriminatory practices that Congress sought to proscribe in Title III. Looking to the text of Title III, Congress's explicit intent was to prohibit disability-based discrimination in the access to "goods, services, facilities ... of any place of public accommodation by any person who owns, leases (or leases to), or operates a place of public accommodation.. ${ }^{35}$ Accordingly, several judicial inquiries have focused on whether employer-sponsored insurance policies constitute "goods" or "services" of a "place of public accommodation." In making this determination, courts have had first to decide whether "places of public accommodation" are limited to physical facilities, such as insurance office buildings, or whether they include non-

32. See Winslow v. IDS Life Ins. Co., 29 F. Supp. 2d 557, 565-66 (D. Minn. 1998) (addressing whether a denial of long-term disability insurance to an applicant diagnosed with a mental illness violated Title III); Pallozzi v. Allstate Life Ins. Co., 998 F. Supp. 204, 209 (N.D.N.Y. 1998) (examining whether an insurer's refusal to issue a joint life insurance policy to an applicant suffering from major depression violated Title III); Cloutier v. Prudential Ins. Co., 964 F. Supp. 299, 302 (N.D. Cal. 1997) (deciding whether denial of life insurance to an applicant based on the applicant's partner's HIV status violated Title III); Doukas v. Metropolitan Life Ins. Co., 950 F. Supp. 422, 429 (D.N.H. 1996) (addressing whether the denial of an application for mortgage disability insurance based on the applicant's past diagnosis of bipolar disorder violates Title III); Kotev v. First Colony Life Ins. Co., 927 F. Supp. 1316, 1316 (C.D. Cal. 1996) (examining whether an insurer's denial of life insurance policy based on the applicant's spouse's HIV-positive status violates Title III); Baker v. Hartford Life Ins. Co., No. 94 C 4416, 1995 WL 573430 , at *3 (N.D. Ill. Sept. 28, 1995) (deciding whether the denial of health insurance coverage to an eleven-year-old with a history of seizures violated Title III); Pappas v. Bethesda Hosp. Ass'n, 861 F. Supp. 616, 617 (S.D. Ohio 1994) (adjudicating the question of whether the denial of family health insurance to applicant violated Title III when the husband of the applicant had received treatment for hypertension and hyperlipidemia and her son was a paraplegic).

33. See Chabner v. United of Omaha Life Ins. Co., 994 F. Supp. 1185, 1190-92 (N.D. Cal. 1998) (addressing whether a life insurer's charge of a higher rate for a policy to an applicant suffering from fascioscapulohumeral muscular dystrophy violated Title III).

34. Often the question is more narrowly focused on whether Title III reaches the content of employer-sponsored insurance policies. See, e.g., Parker, 121 F.3d at 1008 (examining whether Title III governs the content of an employer-sponsored long-term disability plan).

35. 42 U.S.C. $§ 12182(a)$ (1994). 
physical places like websites, telephone lines, or any other medium through which insurance policies may be transferred. This question has resulted in a circuit split and vigorous judicial debate.

\section{A. Decisions Broadly Construing "Place of Public Accommodation"}

In 1994, the First Circuit Court of Appeals was among the first to address whether "places of public accommodation" are limited to actual physical places in Carparts Distribution Center, Inc. $v$. Automotive Wholesaler's Ass' $n .{ }^{36}$ The plaintiff in Carparts had been a participant in a medical reimbursement plan offered by the Automotive Wholesalers Association of New England (AWANE) since $1977 .{ }^{37}$ In 1986, the plaintiff was diagnosed as HIV-positive and was subsequently diagnosed with AIDS in $1991 .{ }^{38}$ During this time, the plaintiff submitted reimbursement claims to AWANE for required medical treatment and medications. ${ }^{39}$ With knowledge of the plaintiff's illness, AWANE amended its medical reimbursement plan (effective January 1991) to cap benefits for AIDS-related illnesses at $\$ 25,000 .^{40}$ For any illness not AIDS-related, however, medical reimbursement benefits were capped at $\$ 1$ million for each plan member. ${ }^{41}$ The plaintiff sued AWANE, claiming that the amendment to the plan violated anti-discriminations laws including Title III of the ADA. ${ }^{42}$

The United States District Court for the District of New Hampshire denied the plaintiff's Title III claim, stating that the defendants, including AWANE, "simply do not qualify as 'places of public accommodation." "43 The court explained that it "interprets this definition of public accommodation as being limited to actual physical structures with definite physical boundaries which a person physically enters for the purpose of utilizing the facilities or obtaining services therein." ${ }^{\prime 4}$ Because neither AWANE nor the AWANE medical

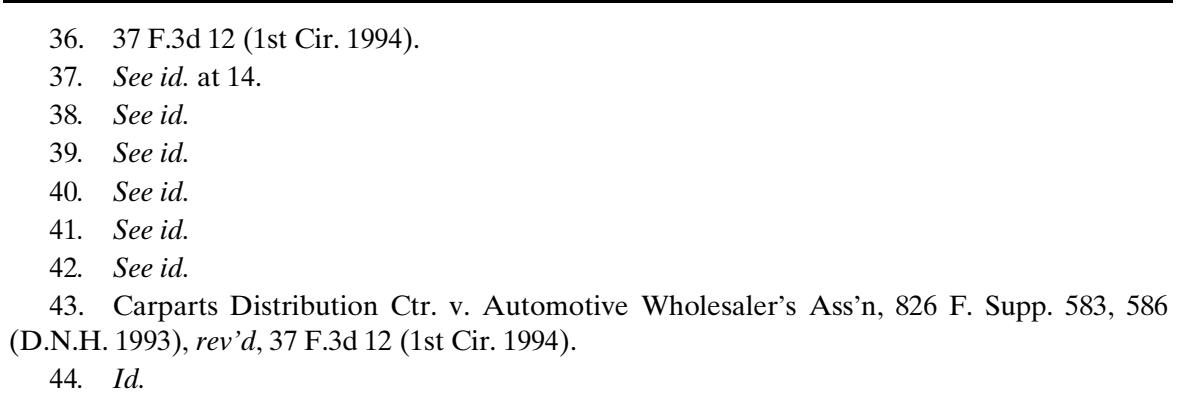


reimbursement plan possessed these characteristics, the district court denied the plaintiff's Title III claim. ${ }^{45}$

Although the court of appeals in Carparts stopped short of determining whether Title III actually governs the content of insurance plans, ${ }^{46}$ it stated with certainty that the district court erred in its narrow interpretation of "place of public accommodation." Examining the language of Title III, the court began its analysis by noting that nothing in the plain language of section 301(7) of the ADA requires a public accommodation to have physical structures that persons can enter. ${ }^{48}$ Moreover, the court reasoned that the inclusion of such entities as "travel services" and "service establishments" in the list of public accommodations in section 301(7) manifested Congress's intent to include entities that do not require persons to enter physical structures to receive services. ${ }^{49}$ Because many "travel services," for example, conduct their business by telephone or mail, customers need not enter any physical structures to obtain the goods or services of a "travel service." concluded that it would be irrational if customers who entered an office of a travel service were protected by the ADA's nondiscrimination provision while those who purchased the exact same services by mail or telephone were not: "Congress could not have intended such an absurd result." ${ }^{11}$

The Carparts court completed its holding that places of public accommodation are not limited to actual physical places by examining the purposes and legislative history of the ADA. The purposes of the ADA, as stated in the text of the statute itself, are to "address the

45. See id.

46. See Carparts, 37 F.3d at 20 (stating that because of possible interpretations of other sections of the ADA, "it is unwise to go beyond the possibility that the plaintiff may be able to develop some kind of claim under Title III"). Because determining whether Title III reaches the content of insurance policies requires a more extended analysis of multiple sources, this Note also stops short of that determination.

47. See id. at 18-19.

48. See id. at 19 (asserting that even if the plain meaning of "public accommodation" were not clear from the text, the term ought not to be limited to physical structures in light of applicable agency regulations and policy concerns).

49. See id.

50. See id.

51. Id. Another example of such an irrational result was provided in Lewis v. Aetna Life Ins. Co., 982 F. Supp. 1158 (E.D. Va. 1997). There, the court noted that "a department store which could not refuse to sell shoes to disabled customers who visited the store's downtown business location could freely refuse services to disabled customers who ordered from the store's catalog." Id. at 1165 . 
major areas of discrimination faced day-to-day by people with disabilities" ${ }^{52}$ and to "provide a clear and comprehensive national mandate for the elimination of discrimination against individuals with disabilities. ${ }^{, 53}$ Furthermore, Congress's oft-quoted purpose in drafting Title III was "to bring individuals with disabilities into the economic and social mainstream of American life ... in a clear, balanced, and reasonable manner." ${ }^{54}$ With this in mind, the court concluded that limiting the applicability of Title III to physical structures that people must enter to obtain goods or services would contravene the remedial purposes of the ADA and frustrate Congress's intent that disabled individuals fully and equally enjoy the "goods, services, privileges and advantages, available indiscriminately to other members of the general public."

Numerous district courts have adopted Carparts's interpretation of "place of public accommodation" and have even gone further than Carparts in holding that Title III governs the content of insurance policies. ${ }^{56}$ These courts have allied themselves with the First Circuit in finding that nothing in the plain language of Title III limits it merely to guaranteeing nondiscrimination in access to physical structures. ${ }^{57}$ Notably, in a recent decision authored by Chief Judge Posner, the Seventh Circuit adopted Carparts's broader construction of "place of public accommodation," noting that places of public accommodation

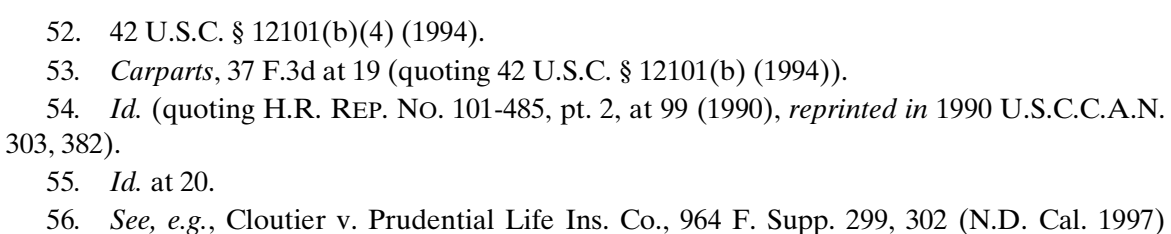
(stating that the reasoning of Carparts and other courts "suffice[s] to persuade this Court of the applicability of Title III to Prudential's denial of plaintiff's application"); Doukas v. Metropolitan Life Ins. Co., 950 F. Supp. 422, 425-26 (D.N.H. 1996) (holding that Title III "would extend to the substance or contents of an insurance policy where, as here, the plaintiff has been denied access to insurance because of his or her disability"); Baker v. Hartford Life Ins. Co., No. 94 C 4416, 1995 WL 573430, at*3 (N.D. Ill. Sept. 28, 1995) (holding that Title III applies when a plaintiff is not physically present at the place of public accommodation but has contact with an insurer through his father by correspondence and telephone). But see Doe v. Mutual of Omaha Ins. Co., 179 F.3d 557, 559-61 (7th Cir. 1999) (adopting Carparts's broader reading of "place of public accommodation" in a remarkably similar case, but holding that Title III does not govern the content of insurance policies).

57. See, e.g., Conners v. Maine Med. Ctr., 42 F. Supp. 2d 34, 46 (D. Me. 1999) ("[U]nder the plain language of Title III, the Act would extend to the substance or contents of an insurance policy.”); Kotev v. First Colony Life Ins. Co., 927 F. Supp. 1316, 1321 (C.D. Cal. 1996) ("Title III's plain language does not refer to access to physical structures .... [and] does not bar only discrimination in access to physical structures."). 
include entities "whether in physical space or in electronic space." Furthermore, many courts have echoed and augmented the First Circuit's analysis of the purpose, legislative history, and policies underlying the ADA, strengthening the policy arguments in favor of a broad reading of "place of public accommodation." One district court has commented, for example, that because access to adequate healthcare is "integral to a disabled individual's ability to participate in society," arbitrary discrimination in the terms of an insurance policy runs afoul of the stated purpose of the ADA. ${ }^{59}$

Additionally, district courts have furnished arguments in favor of a broad reading of "place of public accommodation" that are not discussed in the First Circuit analysis. In Winslow v. IDS Life Insurance Co. ${ }^{60}$ for example, the United States District Court for the District of Minnesota noted that limiting places of public accommodation to physical structures virtually negates the protections that the ADA provides for the mentally disabled. ${ }^{61}$ If one accepts a narrow reading, the court explained, one would have to accept that Title III's protection of the mentally disabled from discrimination is limited to the circumstance in which a mentally disabled person is denied access to a physical structure. ${ }^{62}$ Another court propounded a similar rationale for a broad reading of "place of public accommodation"; under the ADA, "disabled" persons include not only those with mental and physical impairments but also those regarded as having such impairments and those who have a record of such impairments. ${ }^{63}$ If Title III's nondiscrimination provision guarantees only physical access to places, "then many persons who do not suffer from a physical handicap but are explicitly protected by Title III could bring a Title III claim only if the public accommodation took affirmative steps to block such persons' physical

58. Chief Judge Posner stated:

The core meaning of [section 302(a) of the ADA], plainly enough, is that the owner or operator of a store, hotel, restaurant, dentist's office, travel agency, theater, Web site, or other facility (whether in physical space or in electronic space) that is open to the public cannot exclude disabled persons from entering the facility and, once in, from using the facility in the same way that the nondisabled do.

Mutual of Omaha, 179 F.3d at 559 (citing Carparts, 37 F.3d at 19).

59. World Ins. Co. v. Branch, 966 F. Supp. 1203, 1208 (N.D. Ga. 1997).

60. 29 F. Supp. 2d 557 (D. Minn. 1998).

61. See id. at 562 .

62. See id.

63. See Kotev v. First Colony Life Ins. Co., 927 F. Supp. 1316, 1321-22 (C.D. Cal. 1996). 
access." ${ }^{64}$ The court could not accept that Congress would have intended such an "anomalous result."

Likewise, numerous courts have supported a broad reading of "place of public accommodation" by referring to Title III's definition of discrimination in section 302(b)(2)(A) ${ }^{66}$ For the purposes of Title III's general prohibition of discrimination, the statute provides that discrimination includes, inter alia, the "imposition or application of eligibility criteria that screen out or tend to screen out an individual with a disability" from full enjoyment of goods, services, facilities, etc., ${ }^{67}$ and "failure to make reasonable modifications in policies, practices, or procedures, when such modifications are necessary to afford such goods [and] services ... to individuals with disabilities." ${ }^{68}$ In light of these examples of discriminatory conduct under Title III, some courts have found that limiting "places of public accommodation" to physical places would render such language from the ADA superfluous ${ }^{69}$ or irrelevant. $^{70}$

Thus, beginning with the Carparts decision, courts have relied on the plain language of Title III, applicable DOJ regulations, ${ }^{71}$ the

64. Id. at 1322 .

65. Id. A narrow interpretation of Title III focuses chiefly on physical barriers that would prevent persons with physical disabilities from entering a physical structure (e.g., inaccessible aisles or non-navigable stairs for persons in wheelchairs). According to Kotev, such a reading would be "anomalous" because it "would narrow the application of Title III to bar discrimination against only some of the categories of persons explicitly protected by the ADA," for physical barriers are no impediment to those merely perceived as disabled or for those who are mentally disabled. $I d$. at 1321-22.

66. See, e.g., Winslow, 29 F. Supp. 2d at 562 (analyzing examples of discriminatory actions described in Title III); Chabner v. United of Omaha Life Ins. Co., 994 F. Supp. 1185, 1190 (N.D. Cal. 1998) (same); Kotev, 927 F. Supp. at 1322 (same).

67. 42 U.S.C. $\$ 12182(\mathrm{~b})(2)(\mathrm{A})(\mathrm{i})$ (1994).

68. Id. § 12182(b)(2)(A)(ii).

69. See Chabner, 994 F. Supp. at 1190 ("Finding that Title III applies only to physical barriers to entry would render meaningless the provisions providing for equal access to goods and services .... [and] sections dealing with modifications ... would similarly be superfluous."). In addition, the court noted that a "safe harbor" provision of the ADA for insurers would also be rendered meaningless if Title III did not ordinarily apply to insurance policies. See id.

70. See Winslow, 29 F. Supp. $2 d$ at 562 (noting that some ADA statutory language "would be rendered irrelevant if Title III were held to apply only to physical access to public accommodations").

71. While the First Circuit stated merely that agency regulations weigh in favor of a holding that places of public accommodation are not limited to actual physical structures, see Carparts Distribution Ctr. v. Automotive Wholesaler's Ass'n, 37 F.3d 12, 19 (1st Cir. 1994), other courts have used agency regulations as support for the further proposition that Title III governs the content of insurance policies. See Winslow, 29 F. Supp. 2d at 563; Doukas v. Metropolitan Life Ins. Co., 950 F. Supp. 422, 427 (D.N.H. 1996). 
purposes and legislative history of the ADA, policy rationale, and the demands of textual integrity in order to justify an expansive construction of "place of public accommodation." Not surprisingly, other courts have used these exact criteria to justify a diametrically opposite construction.

\section{B. Decisions Narrowly Construing "Place of Public Accommodation"}

In 1997, a highly divided Sixth Circuit, sitting en banc, decided Parker v. Metropolitan Life Insurance Co. ${ }^{72}$ which has since become the leading case adopting a narrow construction of "place of public accommodation." The pivotal issue in Parker was whether an employer-sponsored long-term disability plan was subject to the discrimination prohibitions of Title III. ${ }^{73}$ The long-term disability plan in Parker provided benefits until age sixty-five for individuals suffering from physical disorders. ${ }^{74}$ For persons suffering from mental or nervous disorders, however, the plan only provided benefits for up to twenty-four months, unless the individual was hospitalized or receiving inpatient care at the end of the twenty-four-month period. ${ }^{75}$ A plaintiff suffering from severe depression brought suit against Metropolitan Life, the insurer through which her employer offered the disability plan, when her benefits were terminated after twentyfour months. ${ }^{76}$

The court began its analysis of the plaintiff's Title III claim by examining the statutory text, acknowledging the general nondiscrimination provision in section $302(\mathrm{a})$ and the textual examples of discrimination provided in section $302(\mathrm{~b})(1)(\mathrm{A}) .^{77}$ Agreeing that section 301(7) expressly lists insurance offices as places of public accommodation, the court noted that the plaintiff did not

72. 121 F.3d 1006 (6th Cir. 1997) (en banc).

73. See id. at 1008 .

74. See id.

75. See id. Other courts ruling on similar facts have adopted Parker's narrow construction of "place of public accommodation." See Ford v. Schering-Plough Corp., 145 F.3d 601, 612 (3d Cir. 1998) (holding that disability benefits provided to employees are not public accommodations, and thus not covered by Title III); Erwin v. Northwestern Mut. Life Ins. Co., 999 F. Supp. 1227, 1233 (S.D. Ind. 1998) ("Having no binding precedent to follow . . . we regard the Sixth Circuit's approach as the correct one."). But see, e.g., Lewis v. Aetna Life Ins. Co., 982 F. Supp. 1158, 1165 (E.D. Va. 1997) (adopting a broader view of "place of public accommodation" under similar facts).

76. See Parker, 121 F.3d at 1008.

77. See id. at 1010 . 
seek a good or service of an insurance office but rather obtained a benefit plan provided by her private employer that was issued by Metropolitan Life. ${ }^{78}$ The court further stated that "[a] benefit plan offered by an employer is not a good offered by a place of public accommodation.... [because under section 301(7)] a public accommodation is a physical place." the employer-sponsored long-term disability plan was not a good offered by a place of public accommodation because the plaintiff could not physically walk into the offices of Metropolitan Life and obtain such plan. ${ }^{80}$

In adopting a narrow construction of "place of public accommodation," the Parker court relied on applicable DOJ regulations. Previously, the Sixth Circuit had emphasized that the prohibitions of Title III are limited to places of public accommodation. ${ }^{81}$ Applicable DOJ regulations define "place of public accommodation" as "a facility, operated by a private entity, whose operations affect commerce and fall within at least one of" the twelve categories listed in section 301(7). ${ }^{82}$ Regulations define "facility" as "all or any portion of buildings, structures, sites, complexes, equipment, rolling stock or other conveyances, roads, walks, passageways, parking lots, or other real or personal property, including the site where the building, property, structure, or equipment is located." ${ }^{, 3}$ All of these are physical structures or places. In light of these regulatory definitions, the court stated that it would contravene the plain meaning of Title III to hold that places of public accommodation are not limited solely to physical places. ${ }^{84}$ It followed then that because there is no nexus between an insurance policy

\footnotetext{
78. See id.

79. Id.

80. See id. at 1011.

81. See id. (citing Stoutenborough v. NFL, Inc., 59 F.3d 580, 583 (6th Cir. 1995)).

82. Id. (quoting 28 C.F.R. $\$ 36.104$ (1999)).

83. Id. (quoting 28 C.F.R. $\$ 36.104)$.

84. See id. (citing Stoutenborough, 59 F.3d at 583); accord Erwin v. Northwestern Mut. Life Ins. Co., 999 F. Supp. 1227, 1233 (S.D. Ind. 1998) ("The establishments enumerated in [section 301(7)] clearly show that a 'place of public accommodation' is a physical place ...."); Pappas v. Bethesda Hosp. Ass'n, 861 F. Supp. 616, 620 (S.D. Ohio 1994) (stating that places of public accommodation, as defined in section 301(7), are all "splaces' within the plain meaning of that word").
} 
offered by an employer and an insurance office building, Title III did not apply to the policy. ${ }^{85}$

The court found further support for a narrow reading of "place of public accommodation" in the DOJ regulations' explanation of Title III's applicability to wholesale establishments. ${ }^{86}$ These regulations state that wholesale establishments are covered "as places of public accommodation except in cases where they sell exclusively to other business and not individuals. ${ }^{, 87}$ For example, if a food grower supplies food to a food processing corporation on a wholesale basis, it does not become a public accommodation subject to Title III's provisions, but if it operates a roadside stand selling crops directly to the public, it is subject to Title III with respect to operation of that roadside stand. ${ }^{88}$ Parker likened an insurance company to a wholesale crop supplier, reasoning that because Metropolitan Life provided insurance on a wholesale basis to an employer and not to individuals, the insurance company's policies were not subject to Title III; "no place of public accommodation" was involved. ${ }^{89}$

Parker also directly criticized Carparts's rationale for a broad construction of "place of public accommodation" as contrary to proper statutory construction..$^{90}$ Carparts reasoned that places of public accommodation, such as travel services, could not be limited to actual physical places, since it would be absurd for persons procuring services at an office to have the protections of Title III while those who procured the same services by phone or mail did not. ${ }^{91}$ Parker asserted that in reaching this conclusion, the First Circuit

85. See Parker, 121 F.3d at 1011; see also Pallozzi v. Allstate Life Ins. Co., 998 F. Supp. 204, 206 (N.D.N.Y. 1998) ("While the physical structure of an 'insurance office' would be covered under the Act, neither the insurance policy nor an insurance company is a 'place of public accommodation' under the ADA because neither is a physical structure.") (citation omitted).

86. See Parker, 121 F.3d at 1011-12.

87. 28 C.F.R. pt. 36, app. B, at 623 (1999).

88. See id.

89. See Parker, 121 F.3d at 1011-12. The Parker court and others find further support in the regulations for a narrow construction of "place of public accommodation." These courts cite DOJ regulations for the proposition that the ADA does not require entities to alter the mix or nature of the goods that they offer to the public; it follows that the ADA cannot require insurance companies to alter the nature of the insurance policies that they offer to the public. See, e.g., Ford v. Schering-Plough Corp., 145 F.3d 601, 613 (3d Cir. 1998) (adopting the reasoning of the Sixth Circuit in Parker); Parker, 121 F.3d at 1012 (citing 28 C.F.R. pt. 36, app. $\mathrm{B}$, at 630).

90. See Parker, 121 F.3d at 1013-14.

91. See Carparts Distribution Ctr. v. Automotive Wholesaler's Ass'n, 37 F.3d 12, 19 (1st Cir. 1994). 
"disregarded the statutory canon of construction, noscitur a sociis." The doctrine of noscitur a sociis provides that the construction of ambiguous terms should be informed by an analysis of accompanying text "to avoid the giving of unintended breadth to the Acts of Congress." ${ }^{93}$ Parker reasoned that because most of the places of public accommodation listed in section 301(7) are clearly physical places (e.g., theaters, hotels, grocery stores), the ambiguity in terms like "travel service" and "shoe repair service" should be resolved by also limiting them to physical places. ${ }^{94}$ Parker blamed the ambiguous terms on an unimaginative Congress that "simply had no better term than 'service' to describe an office where travel agents provide travel services and a place where shoes are repaired." 95 A broad construction of "place of public accommodation," therefore, would violate the doctrine of noscitur a sociis and the text of the statute. ${ }^{96}$

Other courts, including the Third Circuit Court of Appeals, have adopted both Parker's analysis and its narrow construction of "place of public accommodation. ${ }^{, 97}$ In addition to the arguments set forth in Parker, the Third Circuit noted that restricting "places of public accommodation" to actual physical places is consistent with jurisprudence pertaining to Title II of the Civil Rights Act of 1964, ${ }^{98}$ which prohibits other kinds of discrimination in places of public accommodation. ${ }^{99}$ Although the breadth of "place of public accommodation" under the Civil Rights Act has not been litigated extensively, the Third Circuit noted that the few courts that have spoken on the issue have adopted a narrow construction of the term..$^{100}$

92. Parker, 121 F.3d at 1014.

93. Id. (quoting Jarecki v. G.D. Searle \& Co., 367 U.S. 303, 307 (1961)).

94. See id.

95. Id.

96. See id.

97. See Ford v. Schering-Plough Corp., 145 F.3d 601, 613-14 (3d Cir. 1998) (aligning itself with the Sixth Circuit regarding the definition of "place of public accommodation"); Erwin v. Northwestern Mut. Life Ins. Co., 999 F. Supp. 1227, 1233 (S.D. Ind. 1998) ("Having no binding precedent to follow, and having considered the parties' arguments and reviewed both Parker and Carparts, we regard the Sixth Circuit's approach as the correct one."); Pallozzi v. Allstate Life Ins. Co., 998 F. Supp. 204, 206-07 (N.D.N.Y. 1998) (citing Parker in support of its conclusion that the ADA does not pertain to the underwriting practices of insurance companies).

98. See Ford, 145 F.3d at 613 .

99. See Civil Rights Act of 1964, 42 U.S.C. § 2000a (1994).

100. See Ford, 145 F.3d at 613 (citing Welsh v. Boy Scouts of Am., 993 F.2d 1267, 1269-75 (7th Cir. 1993); Clegg v. Cult Awareness Network, 18 F.3d 752, 755-56 (9th Cir. 1994)). 
Although Parker is the leading case favoring a narrow construction of "place of public accommodation," the decision reflected a highly divided court and included strongly worded dissents. ${ }^{101}$ One dissenting judge criticized the majority's narrow construction of "place of public accommodation," noting that commerce is increasingly becoming electronic either through the Internet, mail, telephone, or other communications media: ${ }^{102}$ "Unfortunately, under the majority view, the same technological advances that have offered disabled individuals unprecedented freedom may now operate to deprive them of rights that Title “‘3(c3.3( ts that)7sthat)7(0.195 
portions of the DOJ regulations in its opinion, ${ }^{108}$ it seems unlikely that the First Circuit was unaware of the agency's resolution of the ambiguity that inheres in the term "place of public accommodation." Rather, it is more likely that the First Circuit implicitly rejected the Department of Justice's definition of "place of public accommodation" as "manifestly contrary to the statute." and legislative history analyses conducted by the First Circuit justify foregoing judicial deference to the agency interpretation in this case. After conducting a normative analysis of the breadth of "place of public accommodation" in Part IV, this Note will further examine validity of these particular DOJ regulations.

\section{Insurance Cases Need Not Turn on This Determination}

Ironically, while the debate over the meaning of "place of public accommodation" has been most vigorous in insurance cases, the question of whether Title III applies to the content of insurance policies need not turn on this determination. Although a comprehensive analysis of all ADA provisions relating to the content of insurance policies is beyond the scope of this Note, a brief mention of alternative analyses will illustrate how Title III may reach the content of insurance policies regardless of a court's interpretation of "place of public accommodation."

A careful look at existing Title III jurisprudence reveals that a court's determination of the scope of "place of public accommodation" is not a necessary predicate to determining whether Title III governs the content of insurance policies. Or, perhaps more appropriately stated, courts determining that the ADA governs the content of insurance policies are not bound also to interpret "place of public accommodation" broadly. As previously stated, a number of courts have adopted a broad construction of "place of public accommodation" and held that Title III governs the content of insurance policies. ${ }^{110}$ However, the Seventh Circuit recently adopted a

108. See Carparts, 37 F.3d at 18 (citing 28 C.F.R. $§ 36.202$ (1993)).

109. Chevron U.S.A. Inc. v. Natural Resource Defense Council, 467 U.S. 837, 844 (1984) ("[L]egislative regulations are given controlling weight unless they are arbitrary, capricious, or manifestly contrary to the statute.").

110. See, e.g., Cloutier v. Prudential Life Ins. Co., 964 F. Supp. 299, 302 (N.D. Cal. 1997) (adopting a broad construction of Title III and rejecting Prudential's argument that plaintiff had no standing to pursue a Title III claim); Doukas v. Metropolitan Life Ins. Co., 950 F. Supp. 422, 425-26 (D.N.H. 1996) (stating that the "plain language" of the statute supports application of Title III to insurance providers). 
broad construction of the term while holding that Title III does not govern the content of insurance policies. ${ }^{111}$ Also, while a number of courts have constructed the term "place of public accommodation" narrowly and held that Title III does not reach the content of insurance policies, ${ }^{112}$ at least one commentator has argued that the term should be narrowly limited to physical places and that Title III does govern the content of insurance policies. ${ }^{113}$

The mere existence of multiple avenues for achieving the same result in existing insurance-related Title III jurisprudence does not imply that each is equally analytically competent, nor does it imply that analysis of the meaning of "place of public accommodation" in such jurisprudence is unnecessary or tautological. Quite to the contrary, the richest and most analytically rigorous examination of the meaning of "place of public accommodation" emerges from the insurance cases. Still, the ability of courts to achieve similar substantive rulings while disagreeing on the construction of "place of public accommodation," coupled with unique considerations related to insurance, ${ }^{114}$ invites further analysis before adopting a settled meaning of the term. Specifically, important policy rationales at stake in the meaning of "place of public accommodation" come into sharper focus through consideration of Title III's applicability to the policies, practices, and eligibility criteria of membership organizations and athletic competitions.

\section{MEMBERSHIP ORGANIZATIONS}

Outside of insurance-related Title III jurisprudence, a frequently litigated issue is whether Title III applies to membership organizations, such as the NCAA, or athletic programs and competitions. Because a finding that an entity is a "place of public

111. See Doe v. Mutual of Omaha Ins. Co., 179 F.3d 557, 559, 564 (7th Cir. 1999) (concluding that while the ADA prevents insurers from turning down applicants merely on the basis of a disability, it does not prevent insurance companies from imposing "caps" for certain diseases).

112. See, e.g., Ford v. Schering-Plough Corp., 145 F.3d 601, 611-614 (3d Cir. 1998); Parker v. Metropolitan Life Ins. Co., 121 F.3d 1006, 1010-14 (6th Cir. 1997).

113. See Schultz, supra note 13, at 368-79 (arguing that "places of public accommodation" are actual physical places and that Title III governs the content of insurance policies).

114. These unique considerations include, among other things, interpretation of a "safe harbor" provision for insurance companies in section 501(c), consideration of actuarial principles, and the DOJ's statements regarding insurance in its ADA Technical Assistance Manual. 
accommodation," or operates a "place of public accommodation," is the jurisdictional hook on which the applicability of Title III hangs, such a determination is at the heart of each of these inquiries. A brief overview of selected cases addressing Title III's applicability to membership organizations will further inform a normative determination of the meaning of "place of public accommodation."

Title III cases frequently arise when a disabled plaintiff claims a sports organization has violated Title III by failing to reasonably accommodate the disabled person or by failing to make exceptions to rules or eligibility criteria that otherwise exclude the disabled person. ${ }^{115}$ For example, in one case the parents of a child with attention deficit disorder sought permission from a youth hockey league to allow the child's brother or father to be on the ice with the child during practices to help him focus. ${ }^{116}$ When the organization refused to allow this accommodation, the parents sued, claiming a violation of Title III. ${ }^{117}$ The court took a narrow view of Title III, stating that in order to have a valid claim, plaintiffs must allege denial of access to a physical place. ${ }^{118}$ Because plaintiffs alleged "denial of participation in the youth hockey league instead of denial of access to a place of public accommodation, i.e. the ice rink," plaintiffs did not have a valid Title III claim. ${ }^{119}$ Furthermore, the court held that because membership organizations are unlike other places of public accommodation listed in section 301(7), they do not satisfy the statutory definition. ${ }^{120}$

Other courts have embraced this reasoning. In Brown v. 1995 Tenet ParaAmerica Bicycle Challenge, ${ }^{121}$ for example, a disabled participant in a cross-country bicycle tour brought a Title III claim against the tour organization when it prevented him from participating after he refused to wear a bicycle helmet when operating

115. See, e.g., Tatum v. NCAA, 992 F. Supp. 1114, 1116, 1123 (E.D. Mo. 1998) (refusing to grant an injunction against the NCAA, where a learning disabled plaintiff claimed the NCAA violated the ADA by refusing to recognize a nonstandard, untimed ACT score for the purposes of academic eligibility); Brown v. 1995 Tenet ParaAmerica Bicycle Challenge, 959 F. Supp. 496, 498, 500 (N.D. Ill. 1997) (dismissing the plaintiff's claim that the defendant organization violated the ADA by preventing his participation in a bicycle tour for refusing to wear a helmet on a specially designed tricycle).

116. See Elitt v. U.S.A. Hockey, 922 F. Supp. 217, 218 (E.D. Mo. 1996).

117. See id.

118. See id. at 223.

119. Id.

120. See id.

121. 959 F. Supp. 496 (N.D. Ill. 1997). 
a specially designed tricycle. ${ }^{122}$ There, the court stated that because the plaintiff alleged denial of participation in the bicycle tour rather than denial of access to a physical place, the plaintiff had no valid Title III claim. ${ }^{123}$ Another court, likewise, held that the National Football League, its member clubs, and the media are not places of public accommodation because they are not physical places like those listed in section 301(7) of the ADA. ${ }^{124}$ Essentially, these courts have answered in the negative the question of whether membership organizations themselves constitute "places of public accommodation."

Other courts have taken the opposite view, holding, for example, that a youth baseball league itself constituted a "place of public accommodation." In Shultz v. Hemet Youth Pony League, ${ }^{125}$ the issue presented was whether a youth baseball league violated Title III when it disallowed an eleven-year-old with cerebral palsy to "play down" in a lower age bracket. ${ }^{126}$ The court held that "Title III's definition of 'place of public accommodation' is not limited to actual physical structures with definite physical boundaries. Therefore, [the baseball league is] 'a place of public accommodation' under the ADA irrespective of [its] link to any physical facilities." 127 This holding is notable for two reasons: first, for the proposition that a membership organization can be a "place of public accommodation," and second, that it can be a public accommodation irrespective of any close connection to a physical facility. This second proposition distinguishes the holding from most jurisprudence construing "place of public accommodation" under Title II of the Civil Rights Act of $1964 .{ }^{128}$ Under the Civil Rights Act, membership organizations can be "places of public accommodation," but only if they are closely connected to a particular facility. ${ }^{129}$

122. See id at 498

123. See id. at 498-99 (citing Stoutenborough v. NFL, 59 F.3d 580, 583 (6th Cir. 1995)); accord Elitt, 922 F. Supp. at 223 (rejecting plaintiff's Title III claim because the plaintiff alleged denial of participation in a youth hockey league rather than denial of physical access to the ice rink); Treanor v. Washington Post Co., 826 F. Supp. 568, 569 (D.D.C. 1993) (rejecting plaintiff's Title III claim because the plaintiff alleged failure of a newspaper to review plaintiff's book rather than denial of access to a facility).

124. See Stoutenborough, 59 F.3d at 583.

125. 943 F. Supp. 1222 (C.D. Cal. 1996).

126. Id. at $1223-24$.

127. Id. at 1225 .

128. See, e.g., Welsh v. Boy Scouts of Am., 993 F.2d 1267, 1272 (7th Cir. 1993).

129. See id. 
Still, a number of courts addressing the applicability of Title III to membership organizations have adopted the approach of the courts that have spoken analogously on the Civil Rights Act. For example, in Ganden v. $N C A A,{ }^{130}$ a learning-disabled athlete brought a Title III claim against the NCAA for not accommodating his learning disability in applying academic eligibility requirements. ${ }^{131}$ There, citing a leading Civil Rights Act case, the court stated that "to constitute a 'place of public accommodation,' a membership organization must have 'a close connection to a particular facility.",132 The court further explained that such a close connection is established if the organization is affiliated with a particular facility or if membership in the organization "acts as a necessary predicate to use of the facility." ${ }^{133}$ Notably, this court also asserted that Title III guarantees more than mere access to facilities and that a plaintiff's failure to allege denial of access to a facility is not fatal to a Title III claim. $^{134}$

Thus, a few distinct views of the breadth of "place of public accommodation" emerge from the cases addressing Title III's applicability to membership organizations. As discussed, some courts have taken a narrow view, similar to that taken in Parker, limiting Title III to guaranteeing access to physical places. At least one court has adopted a broad reading of "place of public accommodation," similar to that in Carparts, holding that membership organizations themselves can constitute "places of public accommodation." The third view illustrates a compromise: that membership organizations can constitute "places of public accommodation" when closely connected to a specific facility.

\section{SCOUting FOR A SETtled MeAning of "Place OF PUBLIC ACCOMMODATION"}

Resolving Title III's ambiguous language in the context of its applicability to membership organizations requires consideration of various factors. Accordingly, to reach an appropriate interpretation of Title III, this part considers legal axioms, the underlying purpose of the statute, fairness, the effect of such interpretation, canons of

130. No. 96 C 6953, 1996 U.S. Dist. LEXIS 17368 (N.D. Ill. Nov. 19, 1996).

131. See id. at $* 13$.

132. Id. at *29 (quoting Welsh, 993 F.2d at 1270).

133. Id. at $* 29-30$.

134. See id. at $* 25$. 
statutory interpretation, and comparison with analogous jurisprudence. The ultimate conclusion, that membership organizations are, indeed, "places of public accommodations," requires the adoption of a broad interpretation of the term and calls into question the authority of particular DOJ regulations.

By revealing the practical absurdities of particular constructions of "place of public accommodation," the following hypothetical contributes to a reasoned distinction between the various possible interpretations of the term. Suppose that the Boy Scouts of America issued a mandate that disabled boys would no longer be welcome to enjoy the goods, services, or benefits of membership in the Boy Scouts on account of their disability or perceived disability. ${ }^{135}$ This policy would violate the ADA only if Title III governs the policies and procedures of the Boy Scouts of America. To establish Title III subject matter jurisdiction, a court must determine that the Boy Scouts of America is a "place of public accommodation" or that it operates a "place of public accommodation."

The Boy Scouts of America is a membership organization that does not maintain a close connection to any structural facility. ${ }^{136}$ The organization gives its members opportunities "to participate in group activities and to develop a variety of skills, e.g., camping, cooking, first aid, lifesaving." ${ }^{137}$ Accordingly, activities could take place at any

135. One would think that this sort of mandate is entirely unlikely given its patent unfairness and its effect of ostracizing a boy at the time in his development when he arguably needs support most. That has not, however, prevented the Boy Scouts of America from issuing just such a mandate with respect to exclusion of openly gay boys. The Supreme Court in Boy Scouts of America v. Dale, 120 S. Ct. 2446 (2000), held that in spite of a state nondiscrimination law banning discrimination based on sexual orientation, the Boy Scouts were entitled to exclude openly gay persons from their membership based on the group's First Amendment rights. See $i d$. at 2447. Key to this decision was the Boy Scouts's ability to convince the Court that forced inclusion of an openly gay Scout would significantly affect the group's expression. See id. at 2448. Other than the Boy Scouts's statements in the course of litigation that it disapproves of homosexuality, there was extremely limited evidence before the Court that the Boy Scouts had ever expressed any opinion on sexual orientation. See id. at 2453. Arguably, the Court allowed the Boy Scouts to exempt themselves from civil rights legislation simply by stating that they disagreed with the nondiscrimination principles embodied in the legislation as applied to gays. See id. at 2453. Reading Dale this way would render virtually all nondiscrimination legislation, including the ADA, voluntary and thus nugatory. The hypothetical presented in this Note assumes that the Boy Scouts could not otherwise opt out of compliance with ADA by simply declaring multiple times during the course of litigation that forced inclusion of disabled boys would interfere with the group's expression.

136. See Welsh v. Boy Scouts of Am., 993 F.2d 1267, 1272 (7th Cir. 1993).

137. Dale v. Boy Scouts of Am., 734 A.2d 1196, 1218 (N.J. 1999), rev'd on other grounds, 120 S. Ct. 2446 (2000). 
number of indoor or outdoor locations, although a "typical Boy Scout gathering involves five to eight young boys engaging in supervised interpersonal interaction in a private home." 138 If Title III does not apply to the Boy Scouts, the organization would be completely unaccountable for any discriminatory practices and procedures it employed. That is, if Title III does not cover the Boy Scouts, the organization could flatly exclude all boys with a disability, a history of disability, or who are regarded as having a disability. An aggrieved disabled boy attempting to integrate himself into the social mainstream of American boyhood would be prevented from doing so and would have no remedy in the courts.

It is axiomatic that remedial legislation, like Title III of the ADA, should be construed broadly rather than narrowly. ${ }^{139}$ Without belaboring the purpose and legislative history analysis previously discussed in the insurance cases, ${ }^{140}$ the broad goals of the ADA indicate Congress's desire to provide a "comprehensive national mandate" ${ }^{141}$ to eliminate disability-based discrimination and to "bring persons with disabilities into the economic and social mainstream of American life." 142 Few single instances of discrimination could more fully remove disabled boys from the social mainstream of American life than preclusion from full and equal access to, and enjoyment of, the Boy Scouts. ${ }^{143}$ To construe the ambiguous statutory term in a way that licenses organizations like the Boy Scouts to freely discriminate contravenes the clear intent of Congress.

This hypothetical, though unlikely, demonstrates powerfully why Title III must apply to membership organizations, like the Boy Scouts, that do not maintain a close connection with a structural facility. If Title III applied, it would work to remedy not just egregious instances of intentional discrimination, such as the one described in the hypothetical, but also merely unexamined or thoughtless policies that subtly discriminate against the disabled, such as rigidly enforced age requirements that adversely affect learningdisabled boys.

\footnotetext{
138. Welsh, 993 F.2d at 1272.

139. See Tcherepnin v. Knight, 389 U.S. 332, 336 (1967).

140. See supra Part II.

141. 42 U.S.C. $§ 12101(b)(1)(1994)$.

142. H.R. REP. NO. 101-485, pt. 2, at 22, 99 (1989), reprinted in 1990 U.S.C.C.A.N. 303, 304.

143. Since the Boy Scouts's inception in 1910, over eighty-seven million youths and adults have joined. See Dale v. Boy Scouts of Am., 734 A.2d 1196, 1200 (N.J. 1999), rev'd on other grounds, 120 S. Ct. 2446 (2000).
} 
Also, whether membership organizations like the Boy Scouts are "places of public accommodation" (or operate places of public accommodation) merely confers Title III subject matter jurisdiction; it does not decide whether their conduct or policies in fact discriminate and violate Title III. Subject matter jurisdiction simply allows the court to reach the question of whether certain conduct is discriminatory. In the insurance cases, for example, an insurer would not be liable under Title III if its policies decisions were supported by actuarial data. Furthermore, with respect to the sports cases, Title III would not require organizations to make any exceptions for disabled persons that fundamentally alter the nature of the sport or endanger the health of other players. ${ }^{144}$ In addition, Title III does not require any entity to undertake any measures to accommodate the disabled if such measures would be an undue financial or administrative burden. ${ }^{145}$ Because the substance of Title III protects potential defendants from having to make unreasonable accommodations for the disabled, courts ought not overprotect those who discriminate "by imparting a stingy and narrow reading to the remedial statute at issue." $" 146$

These factors, coupled with the purpose and legislative history of the ADA, as evidence of Congress's intent, weigh heavily in favor of a finding that membership organizations without close ties to a structural facility, like the Boy Scouts, either constitute "places of public accommodation" or operate "places of public accommodation." ${ }^{, 147}$ Since application of Title III to these membership

144. See, e.g., McPherson v. Michigan High Sch. Athletic Ass'n, 119 F.3d 453, 461 (6th Cir. 1997) (upholding an eight-semester eligibility limitation where a waiver of the limitation "would work a fundamental alteration in Michigan high school sports programs"); Sandison v. Michigan High Sch. Athletic Ass'n, 64 F.3d 1026, 1034 (6th Cir. 1995) (rejecting a claim that Title III required a high school sports association to waive its rule limiting eligibility to students under age 19 to accommodate a learning disabled student).

145. See cases cited supra note 144 .

146. Welsh v. Boy Scouts of Am., 993 F.2d 1267, 1279 (7th Cir. 1993) (Cummings, J., dissenting) (rejecting the majority's narrow interpretation of Title II of the Civil Rights Act).

147. In the context of a membership organization with no ties to a structural facility, those findings are essentially the same. That is, if the Boy Scouts cannot exclude disabled persons under Title III, that prohibition applies whether or not the Boy Scouts own, operate, or lease a "place of public accommodation." Alternatively, the organization itself could be considered the "place of public accommodation." In that case, the Boy Scouts (operators of "places of public accommodation") could not discriminate against the disabled "in the full and equal enjoyment of the goods, services, facilities, privileges, advantages, or accommodations" of the Boy Scouts organization (a "place of public accommodation"). 42 U.S.C. $\$ 12182(a)$ (1994). This reading comfortably fits within the text of the statute. The Boy Scouts example calls for the 
organizations comports with Congress's plainly stated intent to eliminate disability-based discrimination and the doctrine of broadly construing remedial statutes, it is the preferable approach. Finding that membership organizations lacking a close connection to a structural facility can constitute "places of public accommodation" requires that "places of public accommodation" not be limited to actual physical places. Furthermore, it requires that Title III not be limited to guaranteeing mere access to physical places. A number of the insurance-related Title III cases support both of these findings. ${ }^{148}$ Thus, the First Circuit's broad construction of "place of public accommodation" in Carparts (supported by the Seventh Circuit) is preferable to the narrow construction of the term provided by the Third and Sixth Circuits. Although each of the circuit courts grounded its construction of "place of public accommodation" in the text of the statute, applicable regulations, legislative history, and public policy, the interpretation that avoids incongruous outcomes outside of the insurance-related context ought to be adopted.

A notable objection to a finding that "places of public accommodation" may be non-physical is that most, and arguably all, of the examples in the text of Title III are physical places. According to this argument, courts adopting the broad interpretation, such as Carparts, cling to a contrived ambiguity in a few definitional examples like "travel service" rather than using the doctrine of noscitur a sociis, which makes manifest that Congress spoke solely of physical places. Membership organizations are so unlike the examples of "places of public accommodation" provided in the statute, the argument continues, that they could not have been within Congress's contemplation.

Two responses to that criticism support the broad interpretation reached herein. First, while noscitur a sociis is a valid canon of construction, one may also give independent meaning to each term listed in the statute. Because noscitur a sociis implies a deliberateness by Congress in selecting the words of the statute, one should presume that the deliberateness of the word choice extends not only to the entire corpus of the statute but to the individual words selected. In rejecting the Carparts court's determination that terms like "travel service" and "shoe repair service" are not necessarily physical places,

determination that such membership organizations themselves constitute "places of public accommodation."

148. See supra Part II. 
the court in Parker mused that "it is likely that Congress simply had no better term than 'service' to describe an office where travel agents provide travel services and a place where shoes are repaired." ${ }^{149}$ While it is not unreasonable to allow context to inform ambiguity, Parker essentially states that when Congress chose the word "service," it actually meant "facility" or "office" or "building." But because Congress, indeed, chose not to use a word like "facility," resolving the ambiguity that inheres in such words as "service" could be better accomplished by integrating the purpose of the statute in question rather than by borrowing meaning from surrounding words. Again, the axiom of interpreting remedial statutes like the ADA broadly supports the interpretation reached in Carparts rather than Parker.

Second, even if one concedes that all of the examples of "place of public accommodation" listed in the statute (including "travel service") are physical places, that still does not mean that "places of public accommodation" are necessarily limited to physical places. Precedent exists for using the law's purpose to guide its application rather than strictly adhering to a textual list of terms. Consider, for example, the U.S. Supreme Court case, Katz v. United States. ${ }^{150}$ There, the Court interpreted the Fourth Amendment, which protects "persons, houses, papers, and effects, against unreasonable searches and seizures." Although all the protected items in the list are tangible, the Court held that conversations overheard by wiretapping are protected under the Fourth Amendment. ${ }^{152}$ Unlike persons, houses, papers, and effects, conversations are distinctly intangible. ${ }^{153}$ The majority justified its holding by stating that "the Fourth Amendment protects people, not places." 154 In a similar vein, a dissenting judge in a Seventh Circuit case considering the application of Title II of the Civil Rights Act argued that the Boy Scouts are a "place of public accommodation": "That Title II should turn on the definition of 'place' is irrational because places do not discriminate; people who own and operate places do." ${ }^{, 155}$ In both cases, protection

\footnotetext{
149. Parker v. Metropolitan Life Ins. Co., 121 F.3d 1006, 1014 (6th Cir. 1997).

150. 389 U.S. 347 (1967).

151. U.S. CONST. amend. IV.

152. See Katz, 389 U.S. at 353.

153. See id. at 365 (Black, J., dissenting). Justice Black argued that because conversations are intangible, they are not protected by the Fourth Amendment. See id. (Black, J., dissenting).

154. Id. at 351 .

155. Welsh v. Boy Scouts of Am., 993 F.2d 1267, 1282 (7th Cir. 1993) (Cummings, J., dissenting).
} 
against invasive or discriminatory conduct, not a strict adherence to a list of examples, guided the interpretation of the law.

Having argued that "places of public accommodation" are not limited to actual physical places, it is appropriate to revisit the question of judicial deference to the DOJ regulations. As previously discussed, applicable DOJ regulations define "place of public accommodation" as a "facility" and further define "facility" by listing undoubtedly physical places. Because the plain meaning of "facility" is a physical place, and in light of the regulatory definition of "facility," a broad interpretation of "place of public accommodation" confers no judicial deference to the agency regulations on this pointthat is, if a court recognizes a membership organization or any other non-physical entity as a "place of public accommodation," it is rejecting a definition that is limited to "facilities." Thus, although no court has explicitly stated it, the regulatory definition is manifestly contrary to the statute and merits no Chevron deference. ${ }^{156}$ Though the regulatory definitions do not explicitly refute any text in the statute, they create "gratuitously cryptic," "self-referential" terms ${ }^{157}$ that, if applied literally, would lead to outcomes manifestly contrary to the purpose of the ADA.

\section{INTERPLAY WITH THE CIVIL RIGHTS ACT OF 1964}

Because Title II of the Civil Rights Act of 1964 also employs the term "place of public accommodation," cases construing the statute provide instructive analysis for courts construing Title III of the ADA. ${ }^{158}$ The leading case construing Title II in this regard is a relatively recent Seventh Circuit case, Welsh v. Boy Scouts of America. ${ }^{159}$ There, the Seventh Circuit considered whether, for the purposes of Title II of the Civil Rights Act of 1964, the Boy Scouts of America constituted a "place of public accommodation." Specifically, the issue was whether the Boy Scouts could exclude members who

156. See Chevron U.S.A. Inc. v. Natural Resources Defense Council, 467 U.S. 837, 843-44 (1984) (holding that courts are not required to defer to agency regulations when they are contrary to the statute).

157. Bowers v. NCAA, 9 F. Supp. 2d 460, 484 (D.N.J. 1998).

158. See, e.g., id. at 484 (noting that "some courts have looked to Title II" for assistance in interpreting Title III); Tatum v. NCAA, 992 F. Supp. 1114, 1121 (E.D. Mo. 1998) (stating that Title II cases "provide instructive analysis in Title III ADA cases"); Elitt v. U.S.A. Hockey, 922 F. Supp. 217, 223 (E.D. Mo. 1996) (applying Title II "for instructive analysis" of the plaintiff's Title III ADA claim)

159. 993 F.2d 1267 (7th Cir. 1993). 
refused to profess a belief in a Supreme Being. ${ }^{160}$ In a 2-1 panel decision, the court ruled that the Boy Scouts was not a "place of public accommodation" because membership organizations lacking a close connection to a physical facility cannot be places of public accommodation. ${ }^{161}$ Like many of the ADA cases that adopt a narrow construction of "place of public accommodation," the Welsh court focused on the physicality of places of public accommodation or their close connection to physical places. ${ }^{162}$ This focus prompted a sharp rebuke from the dissenting judge, who accused the majority of irrationally focusing on places and not the people who discriminate. ${ }^{163}$

A number of factors suggest that Welsh has been weakened since it was decided in 1993. First, in adopting a narrow construction of "place of public accommodation," the Welsh court "placed significant reliance on Title III of the ADA, concluding that Congress also did not intend Title III to apply to membership organizations that are not tied to a particular facility." extensive analysis of Title III and its accompanying regulations in reaching this determination. Furthermore, because the case was argued in 1992, the Welsh court did not have the benefit of the scores of cases examining the meaning of "place of public accommodation": almost every Title III case interpreting "place of public accommodation" was decided after Welsh, mostly notably the decisions of the First, Third, and Sixth Circuits. One must at least query whether the Seventh Circuit would revise its one-paragraph determination that Title III does not govern such membership organizations in light of the hundreds of pages of subsequent judicial analysis of Title III.

Additionally, a recent Seventh Circuit decision arguably cuts into a portion of the Welsh court's analysis. In Doe v. Mutual of Omaha Insurance Co., ${ }^{165}$ the Seventh Circuit asserted that under Title III, "places of public accommodation" include not just physical space but

\footnotetext{
160. See id. at 1268 .

161. See id. at 1270 .

162. See id. at 1271.

163. See id. at 1282 (Cummings, J., dissenting) ("That Title II should turn on the definition of 'place' is irrational because places do not discriminate; people who own and operate places do.").

164. 1 Henry H. Perritt, JR., Americans with Disabilities Act Handbook $§ 15.1 .1$ (3d ed. 1997).

165. 179 F.3d 557 (7th Cir. 1999).
} 
also electronic space. ${ }^{166}$ To support this proposition, it cited Carparts, the leading case establishing that "places of public accommodation" are not limited to actual physical places. ${ }^{167}$ By taking the emphasis off of the physicality of "places of public accommodation," the court arguably undermined the Welsh court's focus on the physicality of "places of public accommodation." That is, if a website or telephone line can be a "place of public accommodation," then perhaps it is unduly limiting to require membership organizations to have a close connection to an actual physical structure to be "places of public accommodation." Since the Welsh court relied heavily on the notion that the Boy Scouts is not analogous to any of the places of public accommodations listed in the statute, it may elect to reconsider that view given that websites and telephone lines are equally unlike the listed entities. ${ }^{168}$

Furthermore, tracing Welsh's journey through subsequent Title III jurisprudence raises questions about the strength of its analysis with respect to Title III of the ADA. First, the court initially relied on a then-unexamined interpretation of Title III, which now is merely one of many such interpretations. Subsequent courts interpreting Title III relied on Welsh as persuasive authority to support a narrow construction of "place of public accommodation." In effect, a oneparagraph consideration of "place of public accommodation" under Title III in 1992 was relied on in shaping the breadth of the term under Title II of the Civil Rights Act, which, in turn, has been relied on in more extensive analyses of Title III to support a narrow construction of the term. Tracing the birthplace of the narrow interpretation of "place of public accommodation" to the Welsh decision is somewhat distressing in light of that case's lean discussion of Title III. It is also somewhat ironic for cases interpreting Title III of the ADA to rely on a Title II decision that relied on a cursory interpretation of Title III.

In light of these considerations, courts construing Title III, while not ignoring the Welsh decision, ought not put undue emphasis on it. But more importantly, if courts construing Title II of the Civil Rights Act look to Title III jurisprudence in construing its terms, then a

166. See id. at 559.

167. See id. (citing Carparts Distribution Ctr. v. Automotive Wholesaler's Ass'n, 37 F.3d 12, 19 (1st Cir. 1994)).

168. For a separate discussion advocating the reversal of Welsh outside of the Title III context, see Edward Bigham, Civil Rights - Seventh Circuit Permits Boy Scouts of America to Exclude Atheist - Welsh v. Boy Scouts of America, 67 TEMP. L. REV. 1333 passim (1994). 
broad construction of "place of public accommodation" under Title III could have a carryover effect into Title II jurisprudence. This has important implications for a number of minorities. It would, for example, subject the Boy Scouts and other similar membership organizations to Title II, barring discrimination based on race, religion, or national origin. This highlights the importance of determining the scope of "place of public accommodation" under Title III of the ADA.

\section{CRITICISMS AND CONCLUSION}

The resolution of ambiguous statutory text is a frequent source of bitter disagreement in American jurisprudence. Contrary to a number of courts that have adopted a narrow construction of "place of public accommodation," this Note places great emphasis on the purposes of the ADA and the broad construction of remedial legislation. The conclusion, that a "place" in Title III does not actually have to be a physical place, no doubt provokes the distaste of those tremulous at the thought of rampant unprincipled superlegislating by courts. In fact, a good example of a likely criticism of this Note's thesis is evident in Justice Black's dissent in Katz:

I do not believe that it is the proper role of this Court to rewrite the [Fourth] Amendment in order 'to bring it into harmony with the times' and thus reach a result that many people believe to be desirable. While I realize that an argument based on the meaning of words lacks the scope, and no doubt the appeal, of broad policy discussions and philosophical discourses ... for me the language of the Amendment is the crucial place to look in construing a written document such as our Constitution. ${ }^{169}$

Despite this type of criticism, which reflects valid concerns, a stingy reading of "place of public accommodation" constrains Title III's application in a manner inconsistent with its fundamental purpose. The conclusion that "places of public accommodation" are not limited to physical places does not mean that virtually any entity necessarily constitutes a "place of public accommodation." Rather, it focuses the application of Title III on prohibiting discrimination that ostracizes disabled persons from the social and economic mainstream of American life. Like the Civil Rights Act, the ADA protects Americans against discrimination by people, not places. Accordingly,

169. Katz v. United States, 389 U.S. 347, 364-65 (1967) (Black, J., dissenting). 
the focus of Title III inquiries is properly placed not on the involvement of a physical structure in the discrimination against the disabled but on the discrimination itself. 